\title{
IOAN CARAGIANI, AO LEITOR, PREFÁCIO DA ODISSEIA DE HOMERO ${ }^{1}$
}

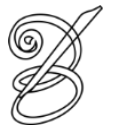 \\ Traduzido por: \\ Natália Oásis de OLIVEIRA* \\ Universidade de Brasília \\ Brasília, Distrito Federal, Brasil \\ Ruxandra INDRES *** \\ Universidade do Oeste de Timisoara \\ Timisoara, Timis, Romênia
}

RECEBIDO EM: 10 de novembro de 2019

ACEITO EM: 30 de novembro de 2019

PUBLICADO EM: abril 2020

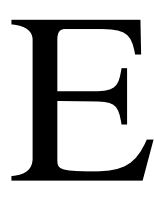

is a Odisseia traduzida para o romeno pela primeira vez. Homero é quem conta em prosa romena o que cantou em versos para os gregos há três mil anos. A ideia que canta a Odisseia é parecida à ideia que cantam os versos romenos: "dorul face poduri peste mari" [a saudade da pátria constrói pontes sobre os mares]. $\mathrm{O}$ amor pela pátria que Odisseu experimenta o impele na luta contra os monstros do mar. Ele consegue vencê-los instigado pelo seu desejo de avistar sua pátria mais uma vez, e assim se sentir feliz em morrer. Nada é tão doce quanto o amor pela pátria. Movido pela saudade de sua amada Penélope, que o espera há 20 anos, e impulsionado pela saudade de ser um senhor, tão benevolente, que faz com que Eumaios, seu criador de porcos, esqueça sua escravidão. A língua na qual se canta essa saudade é a língua da infância do povo grego e essa língua tem relação com o neogrego, semelhante à relação que o romeno utilizado nos livros religiosos estabelece com a língua tida como culta que se utiliza atualmente. Por causa disso é que, para traduzir, eu escolhi a língua do povo, a língua popular, e contornei deliberadamente, na medida do possível, todas as palavras que não se escuta naturalmente no falar do povo. Nesse sentido, não prejudiquei, nem melhorei a língua. Aliás, eu nem o pensei. Meu objetivo era e é completamente diferente. Homero não chega a impressionar o público com os fatos que canta, mas principalmente pela maneira muito particular de contá-las. É por isso que, emprestando-lhe palavras e, sobretudo, 
expressões romenas, ofereci a Homero a oportunidade para que ele conte sua Odisseia à sua maneira. No que diz respeito à tradução de nomes próprios, conservei as formas gregas, acompanhadas de notas com seus equivalentes latinos. As notas de tradução são muito breves e a função delas se limita a facilitar a compreensão dos topônimos mencionados; a brevidade também se deve ao fato de não querer mais repetir os detalhes descritos na tradução da Ilíada. Isso ocorre porque a tradução romena da Ilíada, na qual apresentei observações tanto em relação à escrita de Homero quanto à tradução que eu fiz, estava prevista para ser publicada antes da tradução da Odisseia. Dessa vez, contento-me em resumir alguns elementos mencionados no prefácio da Ilíada. Meu próximo projeto de tradução será Batracomiomaquia, epopeia cômica que faz uma paródia das lutas da Ilíada e da Odisseia.

\footnotetext{
1 Tradução de:

Homerus, Odyssea, traducere în proză de J. Caragiani, Jassy [Iaşi], Tipo-Litografia H. Goldner, 1876. BCU Iaşi, Cota LSIII-4.733.

* Natália Oásis de OLIVEIRA - Bacharel em Letras - Tradução Francês (2018) pela Universidade de Brasília.

152 Mestranda em Estudos da Tradução na mesma instituição. Universidade de Brasília, Instituto de Letras, Programa de Pós-Graduação em Estudos da Tradução. Brasília, Distrito Federal, Brasil.

Currículo acadêmico: http://lattes.cnpq.br/0776722330371198

ORCID: https://orcid.org/0000-0002-1086-9506

E-mail: nataliaoasis@gmail.com

** Ruxandra INDRES - Doutoranda em Tradutologia pela Universidade do Oeste de Timisoara, Romênia. Participou do projeto de tradução de Les traducteurs dans l'histoire (EUV, 2008). Professora adjunta, tradutora e intérprete. Universidade do Oeste de Timisoara, Timișoara, Timis, Romênia.

ORCID: https://orcid.org/0000-0002-7411-4540

E-mail: ruxije_18@yahoo.com
} 